(2) Open Access Full Text Article

\title{
Letter to the editor regarding the article "Prognostic role of long noncoding RNA NEATI in various carcinomas: a meta-analysis"
}

This article was published in the following Dove Press journal:

OncoTargets and Therapy

6 June 2017

Number of times this article has been viewed

$\mathrm{He} \mathrm{Yu}^{1, *}$

Peng Wang ${ }^{2, *}$

Xiong Zhang ${ }^{3}$

'Department of Pathology, Kunming Medical University, ${ }^{2}$ Medical Faculty, Kunming University of Science and Technology, ${ }^{3}$ Department of Vascular Surgery, Kunming Medical University, Chenggong, Kunming, People's Republic of China

*These authors contributed equally to this letter

\section{Dear editor}

With great interest, we read Chen et al's paper entitled "Prognostic role of long noncoding RNA NEAT1 in various carcinomas: a meta-analysis". ${ }^{1}$ The authors stated that high expression of NEAT1 might potentially serve as a reliable biomarker for poor clinical outcome in various cancers.

After reviewing the article, we found an error that should be double checked and be corrected. The data (hazard ratio $[\mathrm{HR}]=2.17,95 \%$ confidence intervals: 0.65-7.23 $P=0.208$ ) Chen et al extracted from Sun et al's paper based on the survival curve indicated that the expression of long noncoding RNA NEAT1 was not related to prognosis, which conflicts with the conclusion of Sun et al. However, Sun et al indicated that the patients with tumors with high NEAT1 expression had a shorter overall survival than patients whose tumors had low NEAT1 expression $(P=0.061){ }^{2}$ As we know that the HR and $P$-values obtained by the curve are offset from the values obtained from the original data calculations, therefore, we suggest the authors contact Sun et al to verify the article data and to obtain the true values. Nevertheless, we still appreciate the authors efforts in studying the correlation between IncRNA NEAT1 and various carcinomas.

\section{Disclosure}

The authors report no conflicts of interest in this communication.

\section{References}

1. Chen T, Wang H, Yang P, He ZY. Prognostic role of long noncoding RNA NEAT1 in various carcinomas: a meta-analysis. Onco Targets Ther. 2017;10:993-1000.

2. Sun C, Li S, Zhang F, et al. Long non-coding RNA NEAT1 promotes non-small cell lung cancer progression through regulation of miR-377-3p-E2F3 pathway. Oncotarget. 2016;7(32):51784-51814
Correspondence: $\mathrm{He} \mathrm{Yu}$

The Kunming General Hospital of the People's Liberation Army, 212 Daguan Road, Kunming, Yunnan Province,

People's Republic of China

Tel +86 I82 88978275

Email yuyuhehe6666@foxmail.com 
Dove Medical Press encourages responsible, free and frank academic debate. The content of the OncoTargets and Therapy 'letters to the editor' section does not necessarily represent the views of Dove Medical Press, its officers, agents, employees, related entities or the OncoTargets and Therapy editors. While all reasonable steps have been taken to confirm the content of each letter, Dove Medical Press accepts no liability in respect of the content of any letter, nor is it responsible for the content and accuracy of any letter to the editor.

\section{Publish your work in this journal}

OncoTargets and Therapy is an international, peer-reviewed, open access journal focusing on the pathological basis of all cancers, potential targets for therapy and treatment protocols employed to improve the management of cancer patients. The journal also focuses on the impact of management programs and new therapeutic agents and protocols on patient perspectives such as quality of life, adherence and satisfaction. The manuscript management system is completely online and includes a very quick and fair peer-review system, which is all easy to use. Visit http://www.dovepress.com/testimonials.php to read real quotes from published authors.

Submit your manuscript here: http://www.dovepress.com/oncotargets-and-therapy-journal 